OPEN ACCESS

Edited by:

Tong Lee,

NASA Jet Propulsion Laboratory

(JPL), United States

Reviewed by:

Yi Chao,

University of California, Los Angeles,

United States

Zhiijin Li,

NASA Jet Propulsion Laboratory

(JPL), United States

*Correspondence:

Pierre De Mey-Frémaux

pierre.de-mey@legos.obs-mip.fr

Specialty section: This article was submitted to

Coastal Ocean Processes,

a section of the journal

Frontiers in Marine Science

Received: 13 November 2018

Accepted: 05 July 2019

Published: 23 July 2019

Citation:

De Mey-Frémaux P, Ayoub N,

Barth A, Brewin R, Charria G,

Campuzano F, Ciavatta S, Cirano M,

Edwards CA, Federico I, Gao S,

Garcia Hermosa I, Garcia Sotillo M,

Hewitt $H$, Hole LR, Holt J, King R,

Kourafalou V, LU Y, Mourre B,

Pascual A, Staneva J, Stanev EV,

Wang $H$ and Zhu $X$ (2019)

Model-Observations Synergy

in the Coastal Ocean

Front. Mar. Sci. 6:436.

doi: 10.3389/fmars.2019.00436

\section{Model-Observations Synergy in the Coastal Ocean}

\author{
Pierre De Mey-Frémaux ${ }^{1 *}$, Nadia Ayoub ${ }^{1}$, Alexander Barth², Robert Brewin ${ }^{3}$, \\ Guillaume Charria ${ }^{4}$, Francisco Campuzano ${ }^{5}$, Stefano Ciavatta ${ }^{3}$, Mauro Cirano 6 , \\ Christopher A. Edwards 7 , Ivan Federico ${ }^{8}$, Shan $\mathrm{Gao}^{9}$, Isabel Garcia Hermosa ${ }^{10}$, \\ Marcos Garcia Sotillo ${ }^{10,11}$, Helene Hewitt ${ }^{12}$, Lars Robert Hole ${ }^{13}$, Jason Holt ${ }^{14}$, \\ Robert King ${ }^{12}$, Villy Kourafalou ${ }^{15}$, Youyu Lu ${ }^{16}$, Baptiste Mourre ${ }^{17}$, Ananda Pascual ${ }^{18}$, \\ Joanna Staneva ${ }^{19}$, Emil V. Stanev ${ }^{19}$, Hui Wang ${ }^{9}$ and Xueming Zhu ${ }^{9}$
}

\footnotetext{
${ }^{1}$ Laboratoire d'Etudes en Géophysique et Océanographie Spatiales, Toulouse, France, ${ }^{2}$ GeoHydrodynamics and Environment Research Group, University of Liège, Liège, Belgium, ${ }^{3}$ National Centre for Earth Observation, Plymouth Marine Laboratory, Plymouth, United Kingdom, ${ }^{4}$ Laboratoire d'Océanographie Physique et Spatiale, Plouzané, France, ${ }^{5}$ MARETEC - Marine Environment and Technology Center, Instituto Superior Técnico, Universidade de Lisboa, Lisbon, Portugal, ${ }^{6}$ Department of Meteorology, Institute of Geosciences, Federal University of Rio de Janeiro, Rio de Janeiro, Brazil, ${ }^{7}$ Ocean Sciences Department, University of California, Santa Cruz, Santa Cruz, CA, United States, ${ }^{8}$ Euro-Mediterranean Center on Climate Change, Lecce, Italy, ${ }^{9}$ Key Laboratory of Research on Marine Hazards Forecasting, National Marine Environmental Forecasting Center, Ministry of Natural Resources, Beijing, China, ${ }^{10}$ Mercator Ocean, Ramonville-Saint-Agne, France, ${ }^{11}$ Puertos del Estado, Madrid, Spain, ${ }^{12}$ Met Office, Exeter, United Kingdom, ${ }^{13}$ Norwegian Meteorological Institute, Oslo, Norway, ${ }^{14}$ National Oceanography Centre, University of Southampton, Southampton, United Kingdom, ${ }^{15}$ Department of Ocean Sciences, University of Miami, Miami, FL, United States, ${ }^{16}$ Fisheries and Oceans Canada, Bedford Institute of Oceanography, Dartmouth, NS, Canada, ${ }^{17}$ Sistema d'Observació i Predicció Costaner de les Illes Balears, Palma de Mallorca, Spain, ${ }^{18}$ IMEDEA (CSIC-UIB), Instituto Mediterráneo de Estudios Avanzados, Esporles, Spain, ${ }^{19} \mathrm{Helmholtz}$ Centre for Materials and Coastal Research, Geesthacht, Germany
}

Integration of observations of the coastal ocean continuum, from regional oceans to shelf seas and estuaries/deltas with models, can substantially increase the value of observations and enable a wealth of applications. In particular, models can play a critical role at connecting sparse observations, synthesizing them, and assisting the design of observational networks; in turn, whenever available, observations can guide coastal model development. Coastal observations should sample the two-way interactions between nearshore, estuarine and shelf processes and open ocean processes, while accounting for the different pace of circulation drivers, such as the fast atmospheric, hydrological and tidal processes and the slower general ocean circulation and climate scales. Because of these challenges, high-resolution models can serve as connectors and integrators of coastal continuum observations. Data assimilation approaches can provide quantitative, validated estimates of Essential Ocean Variables in the coastal continuum, adding scientific and socioeconomic value to observations through applications (e.g., sea-level rise monitoring, coastal management under a sustainable ecosystem approach, aquaculture, dredging, transport and fate of pollutants, maritime safety, hazards under natural variability or climate change). We strongly recommend an internationally coordinated approach in support of the proper integration of global and coastal continuum scales, as well as for critical tasks such as community-agreed bathymetry and coastline products.

Keywords: coastal, ocean, observations, models, synergy, synthesis, assimilation, array design 


\section{INTRODUCTION}

The main interface between humans and the ocean occurs in the coastal seas. Major marine industries thrive in this area while citizens make daily use of the coastal ocean for recreation. OceanPredict (formerly GODAE OceanView; Davidson et al., 2019) promotes the proper integration of all ocean scales under an international, operational, dataassimilative, multi-nested modeling framework. A Coastal Ocean Forecasting System (COFS), often targeted toward operational use, involves a combination of appropriate coastal observing and modeling systems (e.g., Kourafalou et al., 2015a; De Mey et al., 2017). The resulting value chain comprises observations made at sea, satellite data, ocean forecasts and analyses providing specific products and services for end users.

Observing systems tend to be spatiotemporally sparse in coastal regions, in comparison to the small scales of ecosystem variability found there. A crucial observational challenge is addressing the variety of important spatial and temporal scales of the coastal continuum, i.e., the seamless transition from the deep ocean to estuaries, through the shelf: observations should sample the multiscale, two-way interactions of estuarine, nearshore, and shelf processes with open ocean processes, while accounting for the different pace of circulation drivers, such as the fast atmospheric and tidal processes and the slower general ocean circulation and climate scales, and for gradients of biological production, from mesotrophic estuaries to oligotrophic oceans.

To fully realize the benefits of coastal observing systems, observations and models must be better integrated within COFS. Observations can be used to guide coastal model development and assessment (see section "Using Observations to Guide Coastal Model Development and Assessment"). In turn, models can be used to connect and interpret sparse coastal observations (see section "Using Models to Connect and Interpret Sparse Coastal Observations"). Data assimilation (DA) and machine learning (ML) can provide quantitative, validated estimates of Essential Ocean Variables and parameters in the coastal continuum (see section "Using Coastal Models to Synthesize Observations"). Models and DA can also be used to design and optimize existing and future observational arrays, with implications on sampling technology and networks (see section "Using Models to Design and Optimize Coastal Observing Systems").

Integration of observations with models can add value to coastal observations and enable a wealth of applications, e.g., monitoring coastal sea-level rise (Ponte et al., 2019), decisionmaking support, marine search and rescue, coastal management under a sustainable ecosystem approach, aquaculture, dredging, transport and fate of pollutants, port operations, maritime and coastal populations safety, hazard analysis under natural variability and climate change. This paper focusses on how science can support coastal operational monitoring and forecasting to that end.

\section{USING OBSERVATIONS TO GUIDE COASTAL MODEL DEVELOPMENT AND ASSESSMENT}

Coupling models are a commonly used path when addressing the complex interactions between different components of the Earth System, but its assessment is challenging. One such example is illustrated by Staneva et al. (2016a,b, 2017) with a focus on the nonlinear feedback between strong tidal currents and windwaves, which can no longer be ignored, in particular in the coastal zone where its role seems to be dominant. The inclusion of wave coupling appears to decrease strong winds through wavedependent surface roughness (Wahle et al., 2017), and changes sea surface temperature, mixing and ocean circulation (Alari et al., 2016), leading to better agreement with in situ and satellite measurements. Comparisons with available atmospheric and oceanic observations also show that the use of the coupled system reduces the prediction errors in the coastal ocean especially under severe storm conditions.

Significant progress has occurred in operational model skill assessment in recent years (e.g., Hernandez et al., 2015). Sotillo et al. (2016) and Pascual et al. (2017) demonstrate the utility of using Lagrangian and multiplatform observations from a single extensive campaign to assess regional and coastal highresolution models in the Alboran Sea. However, many coastal areas remain under-validated due to the shortage of observations. This affects variables such as surface currents, highly demanded by end-users for a widespread number of applications, while observational sources for currents are generally scarce and limited to High-Frequency (HF) radar-covered areas and some mooring stations. Wherever available, HF radars have been shown to be very beneficial for validating high-resolution regional ocean models (Oke et al., 2002; Liu et al., 2009; Wilkin and Hunter, 2013; Lorente et al., 2016a,b; Soto-Navarro et al., 2016; Mourre et al., 2018; Rodrigues, unpublished, 2015). In addition, reliable wave parameters can be inferred from the weaker second-order Doppler spectrum measured by the HF radar (Lorente et al., 2018).

To improve predictions in coastal regions, it is desirable to reduce biases in the models. However, the lack of both subsurface observations and flux data in coastal regions severely hinders progress. An example of this problem is given by the shelf-seas model around the United Kingdom. Graham et al. (2018) demonstrated that increasing the horizontal resolution from 7 to $1.5 \mathrm{~km}$ led to improvements in off-shelf regions, but biases remained largely unchanged over the shelf region. In the North Sea, biases in both surface and bottom temperatures (Figures 1A,B) suggest that stratification errors are linked either to errors in surface forcing or to vertical processes. Experiments with vertical mixing schemes (Luneva et al., 2019) and light attenuation schemes (Figures 1C,D) suggest that changing these would reduce biases in bottom temperatures. However, there are no flux moorings in the North Sea to evaluate the surface forcing and very few (and infrequent) subsurface observations (Figure 1E) to evaluate the full depth seasonal cycle. 

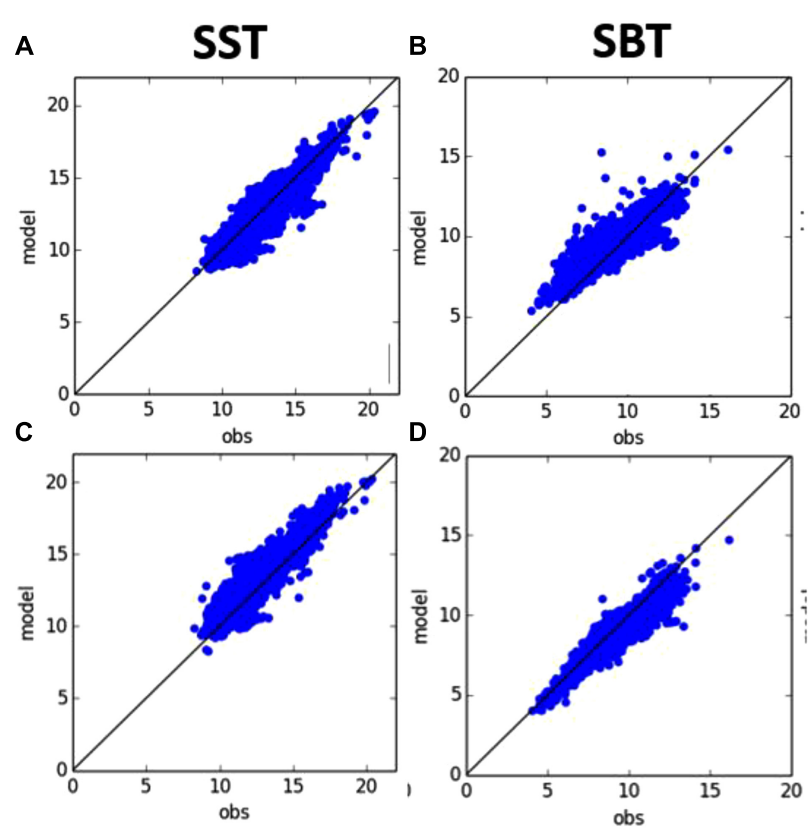

E

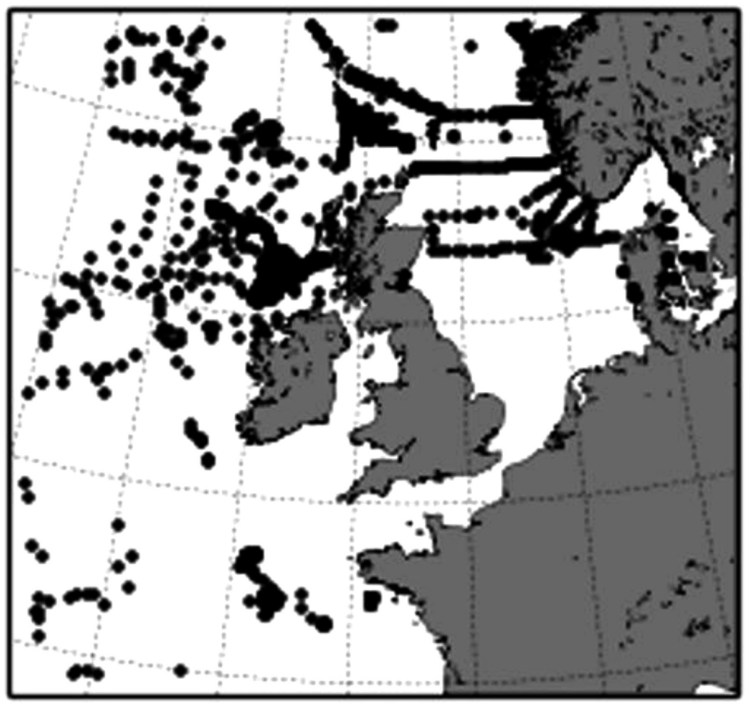

FIGURE 1 | Observed vs. modeled sea surface (A) and sea bottom temperature (B) from profile observations for the current configuration of the Met Office AMM15 shelf seas forecasting system and with proposed changes to the vertical mixing and light attenuation schemes (C,D). Also shown (E) is a map of the location of all temperature profiles for spring 2014 available from EN4.

How valid are direct model-data comparisons? Small spatial scales and HF motions are a major challenge when comparing high-resolution model outputs to observations. Even when a model is deemed realistic, small phase errors can happen, with large consequences if strong gradients (e.g., fronts) are present. High-sampling rate time series are very valuable observations for model assessment or DA, but their representativeness when compared to model outputs remains questionable. This issue has been raised for coastal model assessment (e.g., Sandvik et al., 2016) and methods to overcome such a problem have been developed (e.g., "fuzzy" verification; Ebert, 2008). This may also call for specific strategies for the design of coastal observing networks.

\section{USING MODELS TO CONNECT AND INTERPRET SPARSE COASTAL OBSERVATIONS}

COFS must address the full spectrum of spatial and temporal scales in the coastal continuum. COFS must thus resolve interactions between nearshore, estuarine and shelf processes (target resolution: 10-100 m) and open ocean processes (target resolution: $1 \mathrm{~km}$ ), preferably in a two-way mode. Approaches include downscaling and multi-nesting (e.g., Debreu et al., 2012; Kourafalou et al., 2015b; Trotta et al., 2017), upscaling (SchulzStellenfleth and Stanev, 2016), and unstructured-grid models (e.g., Zhang et al., 2016a,b; Federico et al., 2017; Stanev et al., 2017; Ferrarin et al., 2018; Maicu et al., 2018), and coupling with watersheds (Campuzano et al., 2016, 2018). These features make those COFS more relevant to the interpolation and interpretation of sparse observations.

An example is given in Figure 2, off the northern coast of Cuba, an area of scarce availability in ocean data and the site of an eddy field which was found to play an important role on the broader regional mesoscale processes in the Gulf of Mexico. Kourafalou et al. (2017) describe the related processes using a high-resolution nested model (Kourafalou and Kang, 2012), satellite and in situ data. A series of cyclonic and anticyclonic eddies were identified along the Cuban coast in the Straits of Florida and were traced in model and observational data fields. The anticyclonic eddies were released from the Loop Current and progressed eastward, affecting the overall variability of the Loop Current/Florida Current system, a component of the Gulf Stream. The synthesis of model and observational data has led to a new understanding of the Gulf of Mexico's mesoscale processes, with implications on the predictability of a major western boundary current.

The SAMOA Initiative (Alvarez Fanjul et al., 2018) uses such a synthesis of observation and model products to provide operational products and customized services for port operations in Spain. A suite of increasing-resolution models (down to $\sim 100 \mathrm{~m}$ ), involving wave modeling and improved metocean products, as well as dedicated observational field campaigns and near-real-time networks, is used to downscale CMEMS ${ }^{1}$ products to coastal and port waters, providing enhanced products to end users.

${ }^{1}$ CMEMS: Copernicus Marine Environment Monitoring Service, http://marine. copernicus.eu/. 

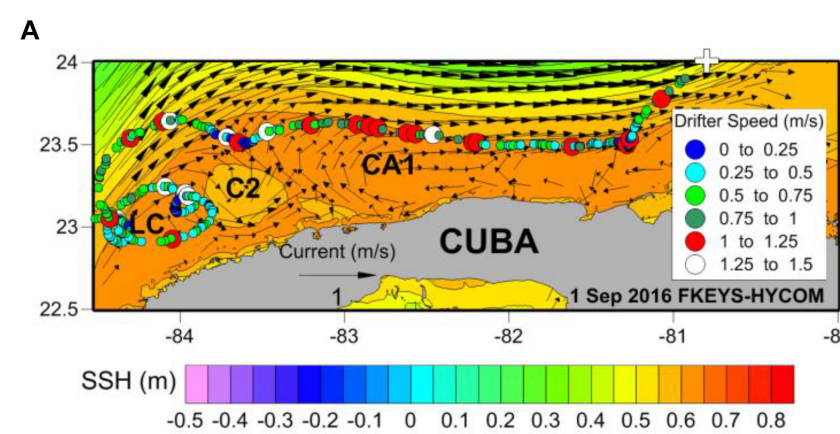

B

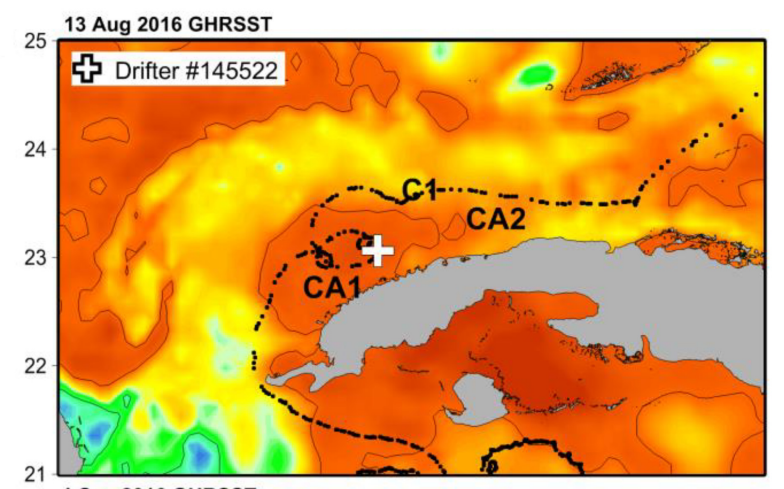

D
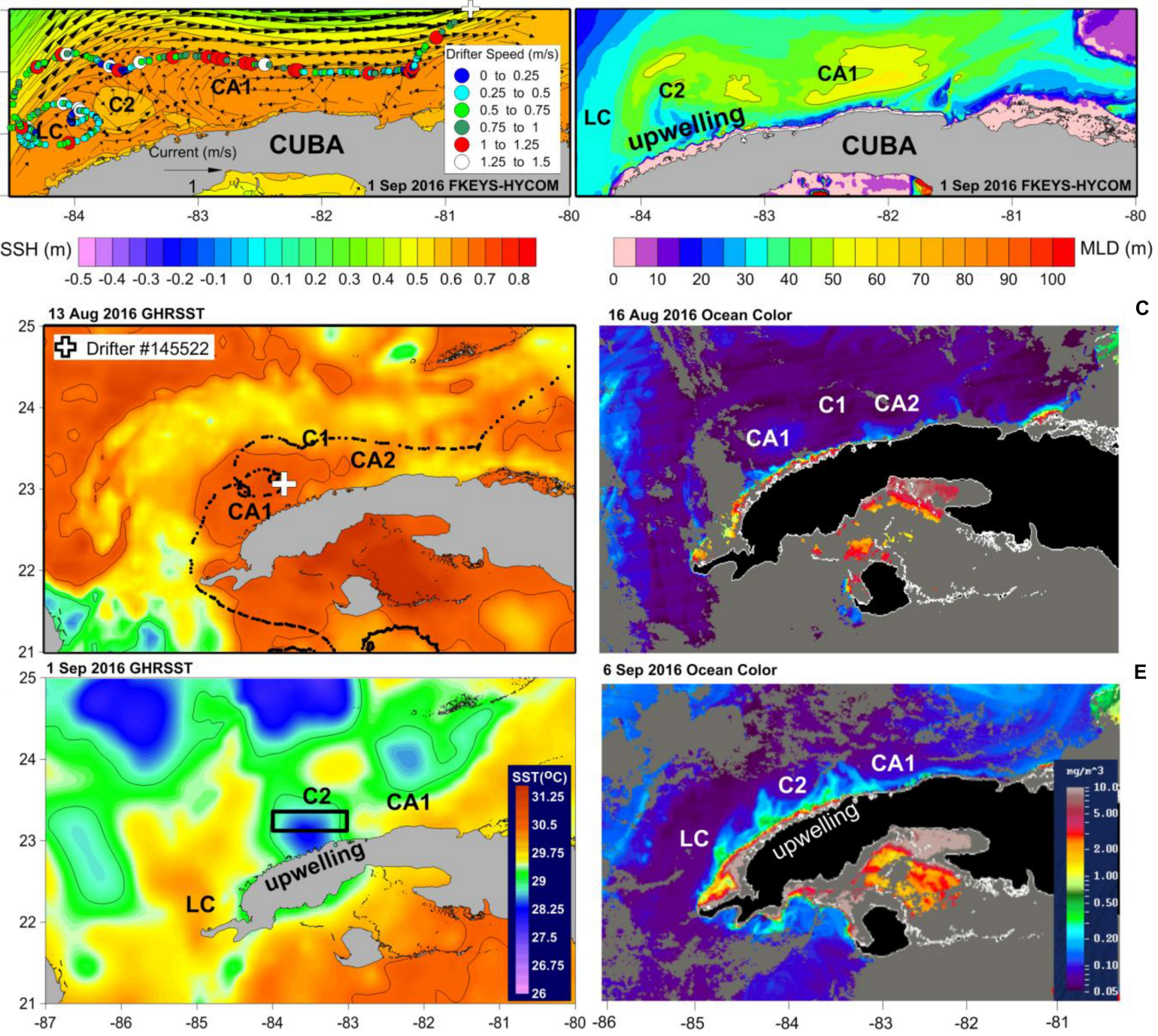

16 Aug 2016 Ocean Color

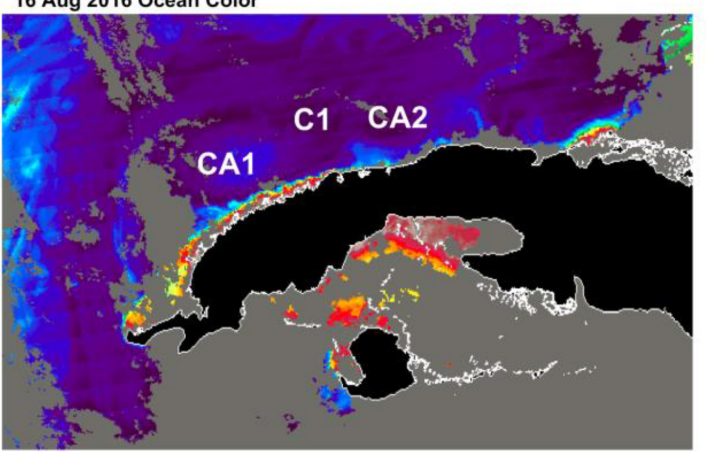

6 Sep 2016 Ocean Color E

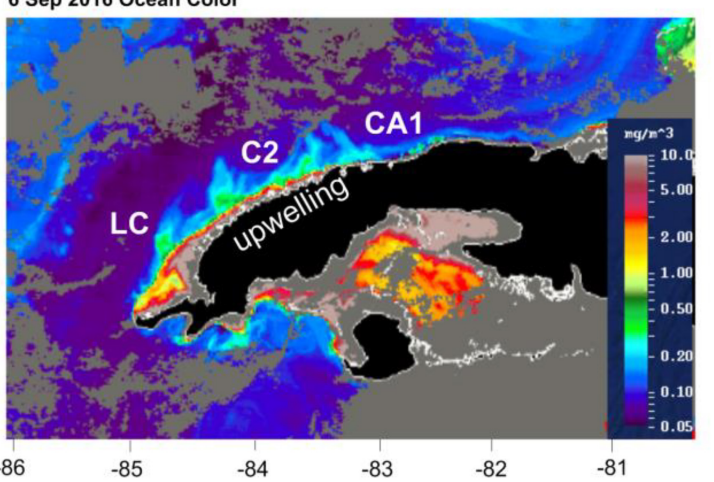

FIGURE 2 | Horizontal distribution of (A) Sea Surface Height (SSH) and near-surface currents and Mixed Layer Depth (MLD) derived from the FKEYS-HYCOM 1/1000 model simulation on September 1, 2016. Horizontal distribution of satellite observations: (B) SST (GHRSST) and (C) satellite ocean color in mid-August 2016 (middle panels) and the respective (D) SST and (E) ocean color in early September 2016 (lower panels). A drifter trajectory along the Straits of Florida is marked on (A), circle colors denoting drifter speed (in $\mathrm{ms}^{-1}$, values in the box insert); speeds over $1 \mathrm{~ms}^{-1}$ (red and white) are marked by larger circles; white cross symbols in panels (A) and (B) indicate the drifter's position on the particular date. The loop current (LC), the cyclonic eddies C1, C2, the anticyclonic eddies CA1, CA2 and the upwelling area along the northern Cuban coast are also marked. "Upwelling" marked over the Cuba land mass indicates upwelling area near the coast (marked by cooler/blue color waters in GHRSST data and more productive/green color waters in ocean color data). We use GHRSST Level 4 SST fields produced by GHRSST daily Level 2 data Donlon et al. (2009), https://podaac.jpl.nasa.gov/dataset/JPL-L4UHfnd-GLOB-MUR, with horizontal resolution of 1-2 km (adapted from Kourafalou et al., 2017).

\section{USING COASTAL MODELS TO SYNTHESIZE OBSERVATIONS}

Let us now turn to DA and ML approaches where models and observations are combined. DA (e.g., Moore and Martin, 2019) is traditionally complex and frustrating in coastal regions because of the multiple scales involved, and also because the data forcing is competing with open-boundary, riverine, and atmospheric forcings (the latter a DA product), which are often imperfectly known.
The value of assimilating HF radar observations to improve the coastal ocean state estimation (Oke et al., 2002; Wilkin et al., 2005; Barth et al., 2008; Shulman and Paduan, 2009; Stanev et al., 2015, 2016) or optimize boundary or surface forcings (Barth et al., 2011) has been demonstrated. Access to original radial radar measurements is important for assimilation (above references; Kurapov et al., 2003; Sperrevik et al., 2015). Reliable error variances and information on the spatially and temporally correlated error structure are very valuable (Vandenbulcke et al., 2016), but are unfortunately often unavailable. 
Altimetry observations have recently been assimilated in shelf-sea systems, including operational systems (e.g., Sotillo et al., 2015; King et al., 2018). Although at an early stage compared with altimetry assimilation in global non-tidal models, use of these observations has the potential to better constrain the coastal mesoscale and the subsurface density structure. However, to derive the maximum benefit from these measurements, sub-surface temperature and salinity fields must already be reasonably well-constrained. The sparseness of profile observations in the shelf seas therefore adds to the challenge. With the upcoming launch of the SWOT wide-swath altimeter mission there will be a step-change in our ability to resolve the ocean mesoscale, but again challenges remain in making use of these low-temporal resolution observations, especially in dynamic shelf regions (cf. Gaultier et al., 2016; Bonaduce et al., 2018). For both nadir altimetry (e.g., Dibarboure et al., 2014) and future wide-swath missions, the complex budget of correlated errors at small scales $(<\sim 30 \mathrm{~km})$ is certainly the main difficulty to overcome.

High-frequency measurements are found to be complementary to altimetry (Pascual et al., 2015); together they provide a strong dynamical control for ocean models (Yu et al., 2012). Other studies also assimilate SST in addition to altimetry (e.g., Vervatis et al., 2016).

Ocean-color is affected by terrestrial organic matter and sediments in case II coastal waters, besides by phytoplankton pigments (IOCCG, 2000). The increased uncertainty of chlorophyll products needs to be accounted in assimilative shelf-sea ecosystem models (Ciavatta et al., 2016) or assimilation of alternative remotely sensed optical data could be considered to constrain biogeochemical simulations, e.g., light attenuation coefficients (Ciavatta et al., 2014) and remote sensing reflectance (Jones et al., 2016).

An important research area where observations and forecasts can be better integrated is related to the development of ML techniques. For instance, Chapman and Charantonis (2017) using iterative self-organizing maps managed to reconstruct the deep ocean currents of the Southern Ocean based on surface information provided by satellites. The algorithm was trained using satellite observations of surface velocity, sea-surface height and sea-surface temperature, as well as observations of the deep current velocity from autonomous Argo floats. ML techniques can also be used in conjunction with numerical models to improve the forecasts. For instance, Kalinic et al. (2017) presented an ocean forecasting system for ocean surface currents for the northern Adriatic coastal area based on self-organizing maps trained by a high-resolution numerical weather prediction model and HF radar data. O'Donncha et al. (2018) in a case-study site in Monterey Bay (California) integrated physics-based models to resolve wave conditions together with a ML algorithm that combines forecasts from multiple, independent models into a single "best-estimate" prediction of the true state. In another example, Wahle et al. (2015) applied a novel approach of DA based on Neural Networks to wave modeling in the German Bight; French et al. (2017) combined artificial neural network with computational hydrodynamics for tidal surge inundation at estuarine ports in the United Kingdom to show that a short-term forecast of extreme water levels can achieve an accuracy that is comparable or better than the United Kingdom national tidal surge model.

\section{USING MODELS TO DESIGN AND OPTIMIZE COASTAL OBSERVING SYSTEMS}

Validated models can contribute to the efficient design and optimization of observing systems for science and operational uses (e.g., Fujii et al., 2019). Approaches include Observing System Simulation Experiments (OSSE), Observing System Experiments (OSE), and Objective Array Design (OAD) are able to handle heterogeneous, multi-platform observing systems: satellite-based, HF radars, buoys with low-cost sensors, autonomous vehicles, etc., OSSE and OSE need an assimilative system, while $\mathrm{OAD}$ does not (e.g., Le Hénaff et al., 2009; Charria et al., 2016; Lamouroux et al., 2016). Such approaches can be adopted in coastal regions to identify gaps in an existing observing network, to study operational failure scenarios, and to assess the potential of future observation types.

OSSE have been conducted in the last decade in the regional ocean (e.g., Halliwell et al., 2014, Halliwell et al., 2015; Aydoğdu et al., 2018). One particular challenge is to develop a rigorous OSSE approach for the interaction of open-sea and coastal scales (with particular focus on coastal scales where observations are sparser and scales shorter) adopting multi-scale models as Nature Runs to back up synthetic observations (e.g., Oke et al., 2015; Fujii et al., 2019).

Using an OSE-type approach, Pein et al. (2016) investigated how salinity measurements in the Ems Estuary affect the reconstruction of the salinity field. Indeed, estuarine and strait dynamics (Stanev et al., 2018), largely dominated by tides and their interaction with buoyancy forcing, provide a new challenge to amalgamating observations and modeling. The approach helped to identify observation locations which are more suitable for model-data synthesis.

Based on existing observing technologies, the use of autonomous platforms (e.g., gliders) or systems deployed on ships of opportunity [e.g., FerryBox, Fishery Observing Systems (FOS)] is worth investigating. The impact of those solutions, identified in previous strategy plans (Morin et al., 2015), has been illustrated in several OSSE, OSE or OAD experiments. It has been shown that assimilating glider observations (hydrology but also velocity) in ocean models does improve modeling systems (e.g., Dobricic et al., 2010; Pan et al., 2011; Jones et al., 2012; Melet et al., 2012; Hernandez-Lasheras and Mourre, 2018). Deploying gliders in coordinated network configurations will further enhance the capacity of the modeling system to reproduce targeted dynamical features (Alvarez and Mourre, 2014). Moreover, long-term repeated glider missions along endurance lines were 
shown to provide a new view of the ocean variability in narrow channels (Heslop et al., 2012) and in the transition zone between coastal and the open ocean (Rudnick et al., 2017). The HF sampling of surface coastal waters by FerryBox systems also delivers observations that improve assimilated model simulations (Korres et al., 2014; Stanev et al., 2016; Aydoğdu et al., 2018). Particularly, in waters where the ocean dynamics are tidally driven, the assimilating FerryBox will be more efficient than slower glider platforms (Charria et al., 2016). To fill gaps between glider tracks and FerryBox commercial lines, FOS appear as a valuable add-on to sample the water column and potentially improve operational predictions (Lamouroux et al., 2016). Aydoğdu et al. (2016) showed that those systems remain efficient even with a limited number of equipped ships if the spatial coverage is adapted to the region dynamics.

Due to the high spatial and temporal variability of the coastal patterns, the observations at the coastal scale may be deployed following an adaptive and relocatable strategy (e.g., autonomous vehicles: Ramp et al., 2009; Mourre and Alvarez, 2012). The effort spent in the recent years to build relocatable model platforms (e.g., De Dominicis et al., 2014; Rowley and Mask, 2014; Trotta et al., 2016) can guide the optimization of this adaptive observing strategy. A recently successful autonomous vessel is the Offshore Sensing SailBuoy ${ }^{2}$, which was used for directional wave measurements in the North Sea (Hole et al., 2016). Being $100 \%$ wind propelled, the SailBuoy has two-way communication via the Iridium network. It has been used for validation of ocean models and remote sensing observations, deployed both in the Arctic and the Gulf of Mexico (Ghani et al., 2014).

\section{CONCLUDING REMARKS}

Models can play a critical role in relation with coastal observations, at connecting sparse observations, synthesizing them, and assisting the design of observational networks. In turn, whenever available, observations can guide coastal model development for research and operational use.

To adequately represent the bidirectional interactions between the open ocean and small-scale processes, a better integration and coordination of coastal and large-scale observation systems would be beneficial. A promising combination would involve $\mathrm{HF}$ radars and reprocessed coastal altimetry data (Gommenginger et al., 2011).

Progress must be made in the next decade on coastal observations, in particular regarding surface currents, subsurface observations and flux data, and strategies must be developed to assess the smallest scales (plumes, fronts, plankton blooms, etc.). Likely upcoming breakthroughs will be Sentinel-3A wind, wave and optical measurements (Heslop et al., 2017; Pahlevan et al., 2017; Schulz-Stellenfleth and

${ }^{2}$ www.sailbuoy.no
Staneva, 2018; Wiese et al., 2018), synthetic aperture radar (SAR)-based wide-swath altimetry (SWOT), the WaCM mission (Rodriguez et al., 2019), and the SKIM ${ }^{3}$ mission, if approved. The availability of accurate, community-agreed bathymetry, reference levels and coastline products are also critical, since without them one cannot get HF processes right nor ensure consistency of coastal models with basin-scale models (e.g., Toublanc et al., 2018). The situation regarding freshwater fluxes and the monitoring of rivers is contrasted (Mishra and Coulibaly, 2009); neither river climatologies nor watershed models are fully satisfactory (Campuzano et al., 2016). Validated observational error estimates must also be a priority.

One of the challenges of coastal ocean observing systems in the next decades is the integration of new and conventional technologies to monitor the variability at small scales and through integration into multiplatform observing and forecasting systems (Tintoré et al., 2013). The establishment of coastal ocean observing systems is being implemented as an important component of marine strategy. These coastal observatories, such as the Integrated Marine Observing System (IMOS) in Australia, the Ocean Observing Initiative (OOI), and the Integrated Ocean Observing System (IOOS) in the United States, Neptune and Venus in Canada, the Coastal Observing System for Northern and Arctic Seas (COSYNA) Project in Germany, Poseidon in Greece, and SOCIB in Spain are today providing new quality controlled observational datasets following standard and international protocols.

New insights on coastal processes can be gained from the measurements of trace elements and isotopes. For instance, radium isotopes (Moore, 2000; Charette et al., 2016) have proven capable of tracing continental waters into the ocean from rivers, estuaries or submarine groundwater discharge.

Finally, coastal areas are ideal in engaging the public in current scientific challenges and raise their awareness on global environmental concerns of immense importance, including global warming and plastic pollution (Cigliano et al., 2015). Citizen science data collected in coastal areas have reached the quality appropriate for exploitation in marine policy (Hyder et al., 2015), coastal area monitoring (Brewin et al., $2015,2017 b$ ) and scientific studies (e.g., for the evaluation of satellite data in coastal regions, Brewin et al., 2017a; Yang et al., 2018). Citizen science data can cover areas that are typically under-sampled by traditional monitoring networks (e.g., intertidal zone) and may offer new opportunities for a quantitative evaluation or assimilation into coastal models. Citizen feedback can even be useful in guiding future observation strategies and model development. Engaging citizens can improve ocean literacy, providing support for future coastal monitoring and modeling (Garcia-Soto et al., 2017). The delivery of sector-focused operational products and services (e.g., Heslop et al., 2019) will progressively allow exploiting and help in developing the full potential of our present

\footnotetext{
${ }^{3}$ https://www.skim-ee9.org/
} 
coastal ocean observing and forecasting capabilities. This will allow in turn receiving the necessary feedback from the user communities to guide future observation and evolution strategies.

\section{REFERENCES}

Alari, V., Staneva, J., Breivik, O., Bidlot, J. R., Mogensen, K., and Janssen, P. A. E. M. (2016). Response of water temperature to surface wave effects in the Baltic Sea: simulations with the coupled NEMO-WAM model. Ocean Dyn. 66:917. doi: 10.1007/s10236-016-0963-x

Alvarez, A., and Mourre, B. (2014). Cooperation or coordination of underwater glider networks? An assessment from observing system simulation experiments in the Ligurian Sea. J. Atmos. Oceanic Technol. 31, 2268-2277. doi: 10.1175/ jtech-d-13-00214.1

Alvarez Fanjul, E., Marcos, G., Gómez, B. P., Valdecasas's, J. G., Rubio’s, S. P., Lorente, P., et al. (2018). "Operational oceanography at the service of the ports," in New Frontiers in Operational Oceanography, eds E. Chassignet, A. Pascual, J. Tintoré, and J. Verron (GODAE: OceanView), 729-736. doi: 10.17125/gov2018. $\operatorname{ch} 27.729$

Aydoğdu, A., Hoar, T. J., Vukicevic, T., Anderson, J. L., Pinardi, N., Karspeck, A., et al. (2018). OSSE for a sustainable marine observing network in the Sea of Marmara, Nonlin. Process. Geophys. 25, 537-551. doi: 10.5194/npg-25-5372018

Aydoğdu, A., Pinardi, N., Pistoia, J., Martinelli, M., Belardinelli, A., and Sparnocchia, S. (2016). Assimilation experiments for the fishery observing system in the Adriatic Sea. J. Mar. Syst. 162, 126-136. doi: 10.1016/j.jmarsys. 2016.03.002

Barth, A., Alvera-Azcárate, A., Beckers, J. M., Staneva, J., Stanev, E. V., and Schulz-Stellenfleth, J. (2011). Correcting surface winds by assimilating highfrequency radar surface currents in the German Bight. Ocean Dyn. 61, 599-610. doi: 10.1007/s10236-010-0369-0

Barth, A., Alvera-Azcárate, A., and Weisberg, R. H. (2008). Assimilation of highfrequency radar currents in a nested model of the West Florida Shelf. J. Geophys. Res. 113:C08033. doi: 10.1029/2007JC004585

Bonaduce, A., Benkiran, M., Remy, E., Le Traon, P. Y., and Garric, G. (2018). Contribution of future wide swath altimetry missions to ocean analysis and forecasting. Ocean Sci. Discuss. 14, 1405-1421. doi: 10.5194/os-2018-58

Brewin, R. J. W., de Mora, L., Jackson, T., Brewin, T. G., and Shutler, J. (2015). On the potential of surfers to monitor environmental indicators in the coastal zone. PLoS One 10:e0127706. doi: 10.1371/journal.pone.0127706

Brewin, R. J. W., de Mora, L., Billson, O., Jackson, T., Russell, P., Brewin, T. G., et al. (2017a). Evaluating operational AVHRR sea surface temperature data at the coastline using surfers. Estuar. Coast. Shelf Sci. 196, 276-289. doi: 10.1016/ j.ecss.2017.07.011

Brewin, R. J. W., Hyder, K., Andersson, A. J., Billson, O., Bresnahan, P. J., Brewin, T. G., et al. (2017b). Expanding aquatic observations through recreation. Front. Mar. Sci. 4:351. doi: 10.3389/fmars.2017.00351

Campuzano, F., Brito, D., Juliano, M., Fernandes, R., de Pablo, H., and Neves, R. (2016). Coupling watersheds, estuaries, and regional ocean through numerical modelling for Western Iberia: a novel methodology. Ocean Dyn. 66, 1745-1756. doi: 10.1007/s10236-016-1005-4

Campuzano, F. J., Juliano, M., Sobrinho, J., de Pablo, H., Brito, D., Fernandes, R., et al. (2018). in Coupling Watersheds, Estuaries and Regional Oceanography through Numerical Modelling in the Western Iberia: Thermohaline Flux Variability at the Ocean-Estuary Interface, ed. E. W. Froneman (Rijeka: IntechOpen). doi: 10.5772/intechopen.72162

Chapman, C., and Charantonis, A. (2017). Reconstruction of subsurface velocities from satellite observations using iterative self-organizing maps. IEEE Geosci. Remote Sens. Lett. 14, 617-620. doi: 10.1109/lgrs.2017.2665603

Charette, M. A., Lam, P. J., Lohan, M. C., Kwon, E. Y., Hatje, V., Jeandel, C., et al. (2016). Coastal ocean and shelf-sea biogeochemical cycling of trace elements and isotopes: lessons learned from GEOTRACES. Philos. Trans. R. Soc. A 374:20160076. doi: 10.1098/rsta.2016.0076

Charria, G., Lamouroux, J., and De Mey, P. (2016). Optimizing observation networks combining gliders, moored buoys and FerryBox in the Bay of Biscay

\section{AUTHOR CONTRIBUTIONS}

All authors listed have made a substantial, direct and intellectual contribution to the work, and approved it for publication.

and english channel. J. Mar. Syst. 162, 112-125. doi: 10.1016/j.jmarsys.2016. 04.003

Ciavatta, S., Kay, S., Saux-Picart, S., Butenschön, M., and Allen, J. I. (2016). Decadal reanalysis of biogeochemical indicators and fluxes in the North West European shelf-sea ecosystem. J. Geophys. Res. Oceans 121, 1824-1845. doi: 10.1002/ 2015 jc011496

Ciavatta, S., Torres, R., Martinez-Vicente, V., Smyth, T., Dall'Olmo, G., Polimene, L., et al. (2014). Assimilation of remotely-sensed optical properties to improve marine biogeochemistry modelling. Prog. Oceanogr. 127, 74-95. doi: 10.1016/j. pocean.2014.06.002

Cigliano, J. A., Meyer, R., Ballard, H. L., Freitag, A., Phillips, T. B., and Wasser, A. (2015). Making marine and coastal citizen science matter. Ocean Coast. Manag. 115, 77-87. doi: 10.1016/j.ocecoaman.2015.06.012

Davidson, F., Chassignet, E., Vinayachandran, P. N., Lu, Y., Smith, G. C., Zhu, X., et al. (2019). Synergies in operational oceanography: the intrinsic need for sustained ocean observations. Front. Mar. Sci. (in press). doi: 10.3389/fmars. 2019.00450

De Dominicis, M., Falchetti, S., Trotta, F., Pinardi, N., Giacomelli, L., Napolitano, E., et al. (2014). A relocatable ocean model in support of environmental emergencies. Ocean Dyn. 64, 667-688. doi: 10.1007/s10236-014-0705-x

De Mey, P., Stanev, E., and Kourafalou, V. (2017). Science in support of coastal ocean forecasting - part 1. Ocean Dyn. 67, 665-668. doi: 10.1007/s10236-0171048-1

Debreu, L., Marchesiello, P., Penven, P., and Cambon, G. (2012). Two-way nesting in split-explicit ocean models: algorithms, implementation and validation. Ocean Mode. 49-50, 1-21. doi: 10.1016/j.ocemod.2012.03.003

Dibarboure, G., Boy, F., Desjonqueres, J. D., Labroue, S., Lasne, Y., Picot, N., et al. (2014). Investigating short-wavelength correlated errors on low-resolution mode altimetry. J. Atmos. Oceanic Technol. 31, 1337-1362. doi: 10.1175/ JTECH-D-13-00081.1

Dobricic, S., Pinardi, N., Testor, P., and Send, U. (2010). Impact of data assimilation of glider observations in the Ionian Sea (Eastern Mediterranean). Dyn. Atmos. Oceans 50, 78-92. doi: 10.1016/j.dynatmoce.2010.01.001

Donlon, C. J., Casey, K. S., Robinson, I. S., Gentemann, C. L., Reynolds, R. W., Barton, I., et al. (2009). The GODAE high-resolution sea surface temperature pilot project. Oceanography 22, 34-45. doi: 10.5670/oceanog. 2009.64

Ebert, E. (2008). Fuzzy verification of high-resolution gridded forecasts: a review and proposed framework. Meteorol. Appl. 15, 51-64. doi: 10.1002/met.25

Federico, I., Pinardi, N., Coppini, G., Oddo, P., Lecci, R., and Mossa, M. (2017). Coastal ocean forecasting with an unstructured grid model in the southern Adriatic and northern Ionian seas. Nat. Hazards Earth Syst. Sci. 17, 45-59. doi: 10.1016/j.marpolbul.2014.10.039

Ferrarin, C., Bellafiore, D., Sannino, G., Bajo, M., and Umgiesser, G. (2018). Tidal dynamics in the inter-connected Mediterranean, Marmara, Black and Azov seas. Prog. Oceanogr. 161, 102-115. doi:10.1016/j.pocean.2018. 02.006

French, J., Mawdsley, E., Fujiyama, T., and Achuthan, K. (2017). Combining machine learning with computational hydrodynamics for prediction of tidal surge inundation at estuarine ports. Proc. IUTAM 25, 28-35. doi: 10.1016/j. piutam.2017.09.005

Fujii, Y., Zuo, H., Oke, P. R., Halliwell, G. R., Gasparin, F., Loose, N., et al. (2019). Observing system evaluation based on ocean data assimilation and prediction systems: on-going challenges and future vision for designing/supporting ocean observational networks. Front. Mar. Sci. (in press). doi: 10.3389/fmars.2019. 00417

Garcia-Soto, C., van der Meeren, G. I., Busch, J. A., Delany, J., Domegan, C., Dubsky, K., et al. (2017). "Advancing citizen science for coastal and ocean research. technical report," in Position Paper 23 of the European Marine Board, eds V. French, P. Kellett, J. Delany, and N. McDonough (Ostend). 
Gaultier, L., Ubelmann, C., and Fu, L.-L. (2016). The challenge of using future SWOT data for oceanic field reconstruction. J. Atmos. Oceanic Technol. 33:119. doi: 10.1175/JTECH-D-15-0160.1

Ghani, M. H., Hole, L. R., Fer, I., Kourafalou, V. H., Wienders, N., Kang, H., et al. (2014). The SailBuoy remotely-controlled unmanned vessel: measurements of near surface temperature, salinity and oxygen concentration in the Northern Gulf of Mexico. Methods Oceanogr. 10, 104-121. doi: 10.1016/j.mio.2014. 08.001

Gommenginger, C., Thibaut, P., Fenoglio-Marc, L., Quartly, G., Deng, X., GómezEnri, J., et al. (2011). "Retracking altimeter waveforms near the coasts," in Coastal Altimetry, eds S. Vignudelli, A. Kostianoy, P. Cipollini, and J. Benveniste (Berlin: Springer).

Graham, J. A., O’Dea, E., Holt, J., Polton, J., Hewitt, H. T., Furner, R., et al. (2018). AMM15: a new high-resolution NEMO configuration for operational simulation of the European north-west shelf. Geosci. Model. Dev. 11, 681-696. doi: 10.5194/gmd-11-6812018

Halliwell, G. R. Jr., Kourafalou, V. H., Le Hénaff, M., Shay, L., and Atlas, R. (2015). OSSE impact analysis of airborne ocean surveys for improving upperocean dynamical and thermodynamical forecasts in the Gulf of Mexico. Prog. Oceanogr. 130, 32-46. doi: 10.1016/j.pocean.2014.09.004

Halliwell, G. R., Srinivasan, A., Kourafalou, V. H., Yang, H., Willey, D., Le Hénaff, M., et al. (2014). Rigorous evaluation of a fraternal twin ocean OSSE system for the open Gulf of Mexico. J. Atmos. Ocean. Techn. 31, 105-130. doi: 10.1175/ JTECH-D-13-00011.1

Hernandez, F., Blockley, E., Brassington, G. B., Davidson, F., Divakaran, P., Drévillon, M., et al. (2015). Recent progress in performance evaluations and near real-time assessment of operational ocean products. J. Operat. Oceanogr. 8, 221-238.

Hernandez-Lasheras, J., and Mourre, B. (2018). Dense CTD survey versus glider fleet sampling: comparing data assimilation performance in a regional ocean model west of Sardinia. Ocean Sci. 14, 1069-1084. doi: 10.5194/os-14-10692018

Heslop, E., Ruiz, S., Allen, J., Lopez-Jurado, J., Renault, L., and Tintoré, J. (2012). Autonomous underwater gliders monitoring variability at "choke points" in our ocean system: a case study in the Western Mediterranean Sea. Geophys. Res. Lett. 39:L20604.

Heslop, E., Tintoré, J., Rotllan, P., Álvarez-Berastegui, D., Fontera, B., Mourre, B., et al. (2019). SOCIB integrated multi-platform ocean observing and forecasting: from ocean data to sector-focused delivery of products and services. J. Operat. Oceanogr. (in press). doi: 10.1080/1755876X.2019.1582129

Heslop, E. E., Saìnchez-Romaìn, A., Pascual, A., Rodrì̀guez, D., Reeve, K. A., FaugeIrre, Y., et al. (2017). Sentinel-3A views ocean variability more accurately at finer resolution. Geophys. Res. Lett. 44, 367-312. doi: 10.1002/2017GL076244

Hole, L. R., Fer, I., and Peddie, D. (2016). Directional wave measurements using an autonomous vessel. Ocean Dyn. 66, 1087-1098. doi: 10.1007/s10236-0160969-4

Hyder, K., Townhill, B., Anderson, L. G., Delany, J., and Pinnegar, J. K. (2015). Can citizen science contribute to the evidence-base that underpins marine policy? Mar. Policy 59, 112-120. doi: 10.1016/j.marpol.2015. 04.022

IOCCG (2000). "Remote sensing of ocean colour in coastal, and other opticallycomplex, waters," in Reports of the International Ocean-Colour Coordinating Group, No. 3, ed. S. Sathyendranath (Dartmouth: IOCCG).

Jones, E. M., Baird, M. E., Mongin, M., Parslow, J., Skerratt, J., Lovell, J., et al. (2016). Use of remote-sensing reflectance to constrain a data assimilating marine biogeochemical model of the Great Barrier Reef. Biogeosciences 13, 6441-6469. doi: 10.5194/bg-13-6441-2016

Jones, E. M., Oke, P., Rizwi, F., and Murray, L. M. (2012). Assimilation of glider and mooring data into a coastal ocean model. Ocean Model. 47, 1-13. doi: 10.1016/j.ocemod.2011.12.009

Kalinic, H., Mihanovic, H., Cosoli, S., Tudor, M., and Vilibic, I. (2017). Predicting ocean surface currents using numerical weather prediction model and Kohonen neural network: a northern Adriatic study. Neural Comput. Appl. 28(Suppl.1), S611-S620.

King, R. R., While, J., Martin, M. J., Lea, D. J., Lemieux-Dudon, B., Waters, J., et al. (2018). Improving the initialisation of the Met Office operational shelf-seas model. Ocean Model. 130:1. doi: 10.1016/j.ocemod.2018.07.004
Korres, G., Ntoumas, M., Potiris, M., and Petihakis, G. (2014). Assimilating ferry box data into the Aegean Sea model. J. Mar. Syst. 140-A, 59-72. doi: 10.1016/j. jmarsys.2014.03.013

Kourafalou, V. H., Androulidakis, Y. S., Kang, H., and Le Hénaff, M. (2017). The dynamics of Cuba anticyclones (CubANs) and interaction with the Loop Current / Florida Current system. J. Geophys. Res. 122, 7897-7923. doi: 10.1002/ 2017JC012928

Kourafalou, V. H., De Mey, P., Le Henaff, M., Charria, G., Edwards, C. A., He, R., et al. (2015a). Coastal Ocean Forecasting: system integration and evaluation. J. Operat. Oceanogr. 8, S127-S146. doi: 10.1080/1755876X.2015.102 2336

Kourafalou, V. H., De Mey, P., Staneva, J., Ayoub, N., Barth, A., Chao, Y., et al. (2015b). Coastal ocean forecasting: science foundation and user benefits. J. Operat. Oceanogr. 8, 147-167.

Kourafalou, V. H., and Kang, H. (2012). Florida Current meandering and evolution of cyclonic eddies along the Florida Keys Reef Tract: are they inter-connected? J. Geophys. Res. 117:C05028. doi: 10.1029/2011JC007383

Kurapov, A. L., Egbert, G. D., Allen, J. S., Miller, R. N., Erofeeva, S. Y., and Kosro, P. (2003). The $M_{2}$ internal tide off Oregon: inferences from data assimilation. J. Phys. Oceanogr. 33, 1733-1757. doi: 10.1175/2397.1

Lamouroux, J., Charria, G., De Mey, P., Raynaud, S., Heyraud, C., Craneguy, P., et al. (2016). Objective assessment of the contribution of the RECOPESCA network to the monitoring of 3D coastal ocean variables in the Bay of Biscay and the English Channel. Ocean Dyn. 66, 567-588. doi: 10.1007/s10236-016-0938-y

Le Hénaff, M., De Meyet, P., and Marsaleix, P. (2009). “Assessment of observational networks with the representer matrix spectra method - application to a 3D coastal model of the Bay of Biscay," in Proceedings of the Workshop on Special Issue of Ocean Dynamics, 2007 GODAE Coastal and Shelf Seas, Vol. 59, (Liverpool), 3-20. doi: 10.1007/s10236-008-0144-7

Liu, Y., MacCready, P., Hickey, B. M., Dever, E. P., Kosro, P. M., and Banas, N. S. (2009). Evaluation of a coastal ocean circulation model for the Columbia River plume in summer 2004. J. Geophys. Res. 114:C00B04. doi: 10.1029/ 2008JC004929

Lorente, P., Piedracoba, S., Sotillo, M. G., Aznar, R., Amo-Baladrón, A., Pascual, A., et al. (2016a). Characterizing the surface circulation in Ebro Delta (NW Mediterranean) with HF radar and modeled current data. J. Mar. Syst. 163, 61-79. doi: 10.1016/j.jmarsys.2016.07.001

Lorente, P., Piedracoba, S., Sotillo, M. G., Aznar, R., Amo-Baladrón, A., Pascual, A., et al. (2016b). Ocean model skill assessment in the NW Mediterranean using multi-sensor data. J. Operat. Oceanogr. 9, 75-92. doi: 10.1080/1755876X.2016. 1215224

Lorente, P., Sotillo, M. G., Aouf, L., Amo-Baladrón, A., Barrera, E., Dalphinet, A., et al. (2018). Extreme wave height events in NW Spain: a combined multi-sensor and model approach. Remote Sens. 10:1. doi: 10.3390/rs10010001

Luneva, M. V., Wakelin, S., Holt, J. T., Inall, M. E., Kozlov, I. E., Palmer, M. R., et al. (2019). Challenging vertical turbulence mixing schemes in a tidally energetic environment: Part I. 3D shelf-sea model assessment. J. Geophys. Res. Oceans (in press). doi: 10.1029/2018JC014307

Maicu, F., De Pascalis, F., Ferrarin, C., and Umgiesser, G. (2018). Hydrodynamics of the Po River-Delta-Sea system. J. Phys. Res. Oceans 123, 6349-6372. doi: 10.1029/2017JC013601

Melet, A., Verron, J., and Brankart, J.-M. (2012). Potential outcomes of glider data assimilation in the Solomon Sea: control of the water mass properties and parameter estimation. J. Mar. Syst. 94, 232-246. doi: 10.1016/j.jmarsys.2011. 12.003

Mishra, A. K., and Coulibaly, P. (2009). Developments in hydrometric network design: a review. Rev. Geophys. 47:RG2001.

Moore, A. M., and Martin, M. J. (2019). Synthesis of ocean observations using data assimilation: toward a more complete picture of the State of the Ocean. Front. Mar. Sci. 6:90. doi: 10.3389/fmars.2019.00090

Moore, W. S. (2000). Determining coastal mixing rates using radium isotopes. Cont. Shelf Res. 20, 1993-2007. doi: 10.1016/s0278-4343(00)00054-6

Morin, P., Krieger, M., Durand, D., Puillat, I., and Farcy, P. (2015). The Joint European Research Infrastructure Network for Coastal Observatories: Achievements and Strategy for the Future. Available at: http://archimer.ifremer. fr/doc/00349/46022/ (accessed November 28, 2015).

Mourre, B., Aguiar, E., Juza, M., Hernandez-Lasheras, J., Reyes, E., Heslop, E., et al. (2018). "Assessment of high-resolution regional ocean prediction systems using 
multi-platform observations: illustrations in the Western Mediterranean Sea," in New Frontiers in Operational Oceanography, eds E. Chassignet, A. Pascual, J. Tintoré, and J. Verron (GODAE: OceanView), 663-694. doi: 10.17125/gov2018. $\operatorname{ch} 24$

Mourre, B., and Alvarez, A. (2012). Benefit assessment of glider adaptive sampling in the Ligurian Sea. Deep Sea Res. I 68, 68-72.

O'Donncha, F., Zhang, Y., Chen, B., and James, S. C. (2018). An integrated framework that combines machine learning and numerical models to improve wave-condition forecasts. J. Mar. Syst. 186, 29-36. doi: 10.1016/j.jmarsys.2018. 05.006

Oke, P. R., Allen, J. S., Miller, R. N., Egbert, G. D., and Kosro, P. M. (2002). Assimilation of surface velocity data into a primitive equation coastal ocean model. J. Geophys. Res. 107:3122. doi: 10.1029/2000JC000511

Oke, P. R., Larnicol, G., Jones, E. M., Kourafalou, V. H., Sperrevik, A. K., Carse, F., et al. (2015). Assessing the impact of observations on ocean forecasts and reanalyses: part 2: regional applications. J. Oper. Oceanogr. 8, S63-S79. doi: 10.1080/1755876X.2015.1022080

Pahlevan, N., Sarkar, S., Franz, B. A., Balasubramanian, S. V., and He, J. (2017). Sentinel-2 MultiSpectral Instrument (MSI) data processing for aquatic science applications: demonstrations and validations. Remote Sens. Environ. 201, 47-56. doi: 10.1016/j.rse.2017.08.033

Pan, C., Yaremchuk, M., Nechaev, D., and Ngodock, H. (2011). Variational assimilation of glider data in Monterey Bay. J. Mar. Res. 69, 331-346. doi: 10.1357/002224011798765259

Pascual, A., Lana, A., Troupin, C., Ruiz, S., Faugère, Y., Escudier, R., et al. (2015). Assessing SARAL/AltiKa delayed-time data in the coastal zone: comparisons with HF radar observations. Mar. Geodesy 8, 260-276. doi: 10.1080/01490419. 2015.1019656

Pascual, A., Ruiz, S., Olita, A., Troupin, C., Claret, M., Casas, B., et al. (2017). A multiplatform experiment to Unravel Meso- and submesoscale processes in an intense front (AlborEx). Front. Mar. Sci. 4:39. doi: 10.3389/fmars.2017.00039

Pein, J. U., Grayek, S., Schulz-Stelleneth, J., and Stanev, E. V. (2016). On the impact of salinity observations on state estimates in Ems Estuary. Ocean Dyn. 66, 243-262. doi: 10.1007/s10236-015-0920-0

Ponte, R. M., Carson, M., Cirano, M., Domingues, C., Jevrejeva, S., Marcos, M., et al. (2019). Towards comprehensive observing and modeling systems for monitoring and predicting regional to coastal sea level. Front. Mar. Sci. (in press). doi: 10.3389/fmars.2019.00437

Ramp, S., Davis, R., Leonard, N., Shulman, I., Chao, Y., Robinson, A., et al. (2009). Preparing to predict: the second autonomous ocean sampling network (AOSN-II) experiment on the Monterey Bay. Deep Sea Res. II 56, 68-87.

Rodriguez, E., Bourassa, M., Chelton, D., Farrar, T., Long, D., Perkovic-Martin, D., et al. (2019). The winds and currents mission concept. Front. Mar. Sci. (in press). doi: 10.3389/fmars.2019.00438

Rowley, C., and Mask, A. (2014). Regional and coastal prediction with the relocatable ocean nowcast/forecast system. Oceanography 27, 44-55. doi: 10. 5670/oceanog.2014.67

Rudnick, D., Zaba, K., Todd, R., and Davis, R. (2017). A climatology of the California current system from a network of underwater gliders. Prog. Oceanogr. 154, 64-106. doi: 10.1016/j.pocean.2017.03.002

Sandvik, A. D., Skagseth, Ø, and Skogen, M. D. (2016). Model validation: issues regarding comparisons of point measurements and high-resolution modeling results. Ocean Model. 106, 68-73. doi: 10.1016/j.ocemod.2016.09.007

Schulz-Stellenfleth, J., and Stanev, E. V. (2016). Analysis of the upscaling problem - a case study for the barotropic dynamics in the North Sea and the German Bight. Ocean Model. 100, 109-124. doi: 10.1016/j.ocemod.2016.02.002

Schulz-Stellenfleth, J., and Staneva, J. (2018). A multi collocation method for coastal zone observations with applications to SENTINEL-3a altimeter wave height data. Ocean Sci. 15, 249-268. doi: 10.5194/os-2018-124

Shulman, I., and Paduan, J. D. (2009). Assimilation of HF radar-derived radials and total currents in the Monterey Bay area. Deep Sea Res. Part II Top. Stud. Oceanogr. 56, 149-160. doi: 10.1016/j.dsr2.2008.08.004

Sotillo, M. G., Amo-Baladrón, A., Padorno, E., Garcia-Ladona, E., Orfila, A., Rodríguez-Rubio, P., et al. (2016). How is the surface Atlantic water inflow through the Gibraltar Strait forecasted? A lagrangian validation of operational oceanographic services in the Alboran Sea and the Western Mediterranean. Deep Sea Res. II 133, 100-117. doi: 10.1016/j.dsr2.2016.05.020
Sotillo, M. G., Cailleau, S., Lorente, P., Levier, B., Aznar, R., Reffray, G., et al. (2015). The MyOcean IBI ocean forecast and reanalysis systems: operational products and roadmap to the future copernicus service. J. Oper. Oceanogr. 8:63. doi: 10.1080/1755876X.2015.1014663

Soto-Navarro, J., Lorente, P., Fanjul, E. A., Sánchez-Garrido, J. C., and GarcíaLafuente, J. (2016). Surface circulation at the Strait of Gibraltar: a combined hf radars and high resolution model study. J. Geophys. Res. Oceans 121, 2016-2034. doi: $10.1002 / 2015 j \mathrm{j} 011354$

Sperrevik, A. K., Christensen, K. H., and Röhrs, J. (2015). Constraining energetic slope currents through assimilation of high-frequency radar observations. Ocean Sci. 11, 237-249. doi: 10.5194/os-11-237-2015

Stanev, E., Schulz-Stellenfleth, J., Staneva, J., Grayek, S., Grashorn, S., Behrens, A., et al. (2016). Ocean forecasting for the German Bight: from regional to coastal scales. Ocean Sci. 12, 1105-1136. doi: 10.5194/os-12-11052016

Stanev, E. V., Grashorn, S., and Zhang, Y. J. (2017). Cascading ocean basins: numerical simulations of the circulation and interbasin exchange in the Azov-Black-Marmara-Mediterranean Seas system. Ocean Dyn. 67, 1003-1025. doi: 10.1007/s10236-017-1071-2

Stanev, E. V., Pein, J., Grashorn, S., Zhang, Y. J., and Schrum, C. (2018). Dynamics of the Baltic Sea Straits via numerical simulation of exchange flows. Ocean Model. 131, 40-58. doi: 10.1016/j.ocemod.2018. 08.009

Stanev, E. V., Ziemer, F., Schulz-Stellenfleth, J., Seemann, J., Staneva, J., and Gurgel, K. W. (2015). Blending surface currents from HF radar observations and numerical modelling: tidal hindcasts and forecasts. J. Atmos. Oceanic Technol. 32, 256-281. doi: 10.1175/jtech-d-1300164.1

Staneva, J., Alari, V., Breivik, O., Bidlot, J.-R., and Mogensen, K. (2017). Effects of wave-induced forcing on a circulation model of the North Sea. Ocean Dyn. 67, 81-101. doi: 10.1007/s10236-016-1009-0

Staneva, J., Wahle, K., Günther, H., and Stanev, E. (2016a). Coupling of wave and circulation models in coastal-ocean predicting systems: a case study for the German Bight. Ocean Sci. 12, 797-806. doi: 10.5194/os-12-797-2016

Staneva, J., Wahle, K., Koch, W., Behrens, A., Fenoglio-Marc, L., and Stanev, E. (2016b). Coastal flooding: impact of waves on storm surge during extremes - a case study for the German Bight. Nat. Hazards Earth Syst. Sci. 16, 2373-2389. doi: 10.5194/nhess-16-2373-2016

Tintoré, J., Casas, B., Heslop, E., Vizoso, G., Pascual, A., Orfila, A., et al. (2013). "The impact of new multi-platform observing systems in science, technology development and response to society needs; from small to large scales," in Computer Aided Systems Theory - EUROCAST, Vol. 8112, eds R. Moreno-Díaz, F. Pichler, and A. Quesada-Arencibia (Berlin: Springer), 341-348.

Toublanc, F., Ayoub, N., Lyard, F., Marsaleix, P., and Allain, D. (2018). Tidal downscaling from the open ocean to the coast: a new approach applied to the Bay of Biscay. Ocean Model. 124, 16-32. doi: 10.1016/j.ocemod.20180 2001

Trotta, F., Fenu, E., Pinardi, N., Bruciaferri, D., Giacomelli, L., Federico, I., et al. (2016). A structured and unstructured grid relocatable ocean platform for forecasting (SURF). Deep Sea Res. Part II 133, 54-75. doi: 10.1016/j.dsr2.2016. 05.004

Trotta, F., Pinardi, N., Fenu, E., Grandi, A., and Lyubartsev, V. (2017). Multinest high-resolution model of submesoscale circulation features in the Gulf of Taranto. Ocean Dyn. 67, 1609-1625. doi: 10.1007/s10236-017-1110-z

Vandenbulcke, L., Beckers, J. M., and Barth, A. (2016). Correction of inertial oscillations by assimilation of $\mathrm{HF}$ radar data in a model of the Ligurian Sea. Ocean Dyn. 67, 117-135. doi: 10.1007/s10236-0161012-5

Vervatis, V., Testut, C. E., De Mey, P., Ayoub, N., Chanut, J., and Quattrocchi, G. (2016). Data assimilative twin-experiment in a high-resolution Bay of Biscay configuration: 4D EnOI based on stochastic modelling of the wind forcing. Ocean Model. 100, 1-19. doi: 10.1016/j.ocemod.2016.01.003

Wahle, K., Staneva, J., and Günther, H. (2015). Data assimilation of ocean wind waves using neural networks. A case study for the German Bight. Ocean Model. 96, 117-125. doi: 10.1016/j.ocemod.2015.07.007

Wahle, K., Staneva, J., Koch, W., Fenoglio-Marc, L., Ho-Hagemann, H., and Stanev, E. (2017). An atmosphere-wave regional coupled model: improving predictions 
of wave heights and surface winds in the Southern North Sea. Ocean Sci. 13, 289-301. doi: 10.5194/os-13-289-2017

Wiese, A., Staneva, J., Schultz-Stellenfleth, J., Behrens, A., Fenoglio-Marc, L., and Bidlot, J. (2018). Synergy between satellite observations and model simulations during extreme events. Ocean Sci. 14, 1503-1521. doi: 10.5194/os2018-87

Wilkin, J., and Hunter, E. (2013). An assessment of the skill of real-time models of Middle Atlantic Bight continental shelf circulation. J. Geophys. Res. Oceans 118, 2919-2933. doi: 10.1002/jgrc.20223

Wilkin, J. L., Arango, H. G., Haidvogel, D. B., Lichtenwalner, C. S., Glenn, S. M., and Hedström, K. S. (2005). A regional ocean modeling system for the long-term ecosystem observatory. J. Geophys. Res. 110:C06S91. doi: 10.1029/ 2003JC002218

Yang, Y., Cowen, L. L., and Costa, M. (2018). Is ocean reflectance acquired by citizen scientists robust for science applications? Remote Sens. 10:835. doi: $10.3390 /$ rs 10060835

Yu, P., Kurapov, A. L., Egbert, G. D., Allen, J. S., and Kosro, P. M. (2012). Variational assimilation of HF radar surface currents in a coastal ocean model off Oregon. Ocean Model. 49-50, 86-104. doi: 10.1016/j.ocemod.2012. 03.001
Zhang, Y. J., Stanev, E., and Grashorn, S. (2016a). Unstructured-grid model for the North Sea and Baltic Sea: validation against observations. Ocean Model. 97, 91-108. doi: 10.1016/j.ocemod.2015.11.009

Zhang, Y. J., Ye, F., Stanev, E. V., and Grashorn, S. (2016b). Seamless cross-scale modelling with SCHISM. Ocean Model. 102, 64-81. doi: 10.1016/j.ocemod. 2016.05.002

Conflict of Interest Statement: The authors declare that the research was conducted in the absence of any commercial or financial relationships that could be construed as a potential conflict of interest.

Copyright ( 2019 De Mey-Frémaux, Ayoub, Barth, Brewin, Charria, Campuzano, Ciavatta, Cirano, Edwards, Federico, Gao, Garcia Hermosa, Garcia Sotillo, Hewitt, Hole, Holt, King, Kourafalou, Lu, Mourre, Pascual, Staneva, Stanev, Wang and Zhu. This is an open-access article distributed under the terms of the Creative Commons Attribution License (CC BY). The use, distribution or reproduction in other forums is permitted, provided the original author(s) and the copyright owner(s) are credited and that the original publication in this journal is cited, in accordance with accepted academic practice. No use, distribution or reproduction is permitted which does not comply with these terms. 